\title{
Emansipasi dalam Bingkai Sejarah Perempuan
}

\author{
Oleh : Tubagus Umar Syarif Hadi Wibowo, M.Pd. \\ Jurusan Pendidikan Sejarah, FKIP, UNTIRTA
}

\section{Umarhadiwibowo90@untirta.ac.id}

“... Wanita dijajah Pria sejak dulu, dijadikan perhiasan sangkar madu, namun ada kala pria tak berdaya tekuk lutut di sudut kerling wanita...."

Kata-kata diatas merupakan penggalan lirik lagu yang cukup terkenal di era tahun sekitar 50-an berjudul Sabda Alam. Lagu yang menggambarkan keadaan saling bertentangan antara dua mahluk utama ciptaan Tuhan di dunia dan sekaligus ironi yang menggelayuti di zamannya. Menarik sekali jika kita menyelami lebih dalam lagi makna lagu yang pernah dipopulerkan penyanyi terkenal Rafika Duri ini, pria yang ditakdirkan berkuasa atas perempuan nan lemah lembut lagi manja terkadang tak berdaya di sudut kerling wanita. Ini memberikan sinyal bagi kaum Pria, jangan sekali-sekali meremehkan kaum hawa!.

Namun dalam kenyataan zamannya, lagu tersebut dapat ditangkap permasalahan seputar wanita yang terus berusaha keluar dari stigma makhluk kelas dua. Sejarah pun nampaknya seakan mendiskriminasi hal tersebut, kaum pria sebagian besar mendominasi dalam gerak langkah sejarah yang terjadi. Bahkan ada anekdot bahwa kata history itu berasal dari dua kata, his yang berarti kata yang menunjukkan kepunyaan (untuk pria) dan story yang berarti cerita.

Jadi dapat diartikan history atau sejarah sebagai ceritanya kaum pria, karena sejarah dianggap hanya berisikan peranan yang dilakukan oleh kaum adam sebagai mesin sejarah tersebut. Tentunya pula tulisan ini tak berkenan menjustifikasi hal tersebut. Ada yang keliru dan harus diluruskan dalam pendapat tersebut. Nyatanya, sejarah tidak selalu berisikan akan keheroikan kaum pria ataupun romantisme dan dinamika kaum pria dalam perjuangan merebut kemerdekaan. Dibalik keheroikan, romantisme, dan dinamika kaum pria dalam sejarah tersembunyi ruh yang menjadi api panas membara dalam mengobarkan semangat sejarah itu. Ruh itu adalah perempuan.

Kajian sejarah perempuan menjadi perhatian utama sejarawan untuk mencari format baru dalam mengkaji berbagai permasalahan seputar perempuan yang melingkupinya, terutama gerakan emansipasi, atau pembebasan perempuan yang sampai sekarang masih diperdebatkan dan terus dikaji. Jika dinjau dari segi penggolongannya, Sartono Kartodirjo (1993:50-51) memasukkan gerakan emansipasi perempuan sebagai gerakan sosial yang didalamnya terdapat proses dinamis 
dari kelompok sosial yang dimobilisasi oleh tujuan dan ideologis, terutama pada fase gerakan itu belum melembaga secara ketat sebagai organisasi formal.

Tuntutan persamaan perempuan dengan laki-laki muncul di Barat pada abad ke-18 bersamaan dengan Reformasi Industri yang mengubah masyarakat dari aristokrat feodalis menuju masyarakat industrial demokratis. Gerakan emansipasi perempuan ini memiliki nama populer yaitu gerakan feminisme sebagai ide revolusioner yang pernah dipandang ada di Barat dan akhirnya menyebar ke berbagai belahan benua. Feminisme sebagai sebuah ide dan gerakan yang berusaha untuk memperoleh pengakuan persamaan kedudukan, derajat, hak dan kewajiban, ini tidak muncul tanpa sebab.

Di dunia Barat (Eropa dan AS) maupun dalam pandangan agama tertentu, kedudukan wanita sebelum ide ini muncul, sungguh memprihatinkan. Sebagai ide yang revolusioner, feminisme berusaha membebaskan perempuan dan laki-laki dari ketertindasan. Perempuan dianggap tertindas karena pemikirannya yang tidak tercerahkan (Ita Mutiara Dewi, 2007:115). Pada intinya feminisme melihat dunia yang ada sejak dulu hingga kini bersikap tidak adil terhadap wanita akibat adanya perbedaan gender (gender differences) yang melahirkan ketidakadilan gender (gender inequalities). Ketidakadilan gender termanifestasi dalam berbagai bentuk ketidakadilan yakni: (1) marginalisasi atau proses pemiskinan ekonomi” (2) subordinasi atau anggapan tidak penting dalam keputusan politik.

\section{Para Pelopor Emansipasi}

Gerakan emansipasi perempuan di Indonesia baru menampakkan taringnya ketika era pergerakan nasional akhir abad ke-19. Sebelumnya, keadaan wanita pada waktu itu (masa kolonial) masih ada dalam konservatisme dan sangat terikat oleh adat. Pengajaran di sekolahsekolah hanya diperuntukkan bagi anak laki-laki, sedangkan anak-anak perempuan hanya mendapat pendidikan di rumah atau lingkungan keluarga dan pendidikan yang diperolehnya tidak lebih dari persiapan untuk menjadi seorang ibu rumah tangga yang baik (Suhartono, 1994). Sampai-sampai ada adagium yang menggambarkan bahwa dinamika kaum Siti Nurbaya itu hanya berkutat pada persoalan di dapur, sumur, bahkan yang lebih ekstrim lagi, kasur.

Adalah Raden Ajeng Kartini, seorang wanita bangsawan yang hidup di tengah-tengah kebudayaan Jawa yang sarat akan nuansa feodalistik kaku, menjadi salah satu pelopor gerakan emansipasi wanita. Ia mempunya gagasan idealisme revolusioner dalam mendobrak konservatism 
dan rigidnya ikatan adat yang mengungkung fleksibilitas wanita untuk dapat membebaskan keinginannya.

Kartini merupakan salah satu dari sedikit perempuan Indonesia yang menguasai Bahasa Belanda dengan baik. Kemampuannya dalam berbahasa Belanda merupakan modal pengetahuan yang amat berharga untuk berhubungan dengan teman-temannya terutama dari Eropa. Korespondensi Kartini dengan wanita modern dari Eropa seperti Steela Zeehandelaar, semakin membuka wawasan khususnya tentang kemajuan wanita. Hal inilah yang mendorong Kartini untuk memajukan kaum wanita Indonesia yang saat itu berada dalam status sosial yang rendah (Sudrajat. 2007:31)

Kartini sangat giat sekali memajukan wanita Indonesia saat itu melalui bidang pendidikan. Hanya melalui pendidikan dan pelajaran yang baik, maka kedudukan dan kebahagiaan wanita dapat diperbaiki dan setaraf dengan kaum pria dalam kehidupan di masyarakat. Hal ini tampak dalam buku Habis Gelap Terbitlah Terang, oleh Kartini terjemahan Armin Pane (Sudiyo, 2002:11). Dalam waktu yang tidak berapa lama cita-cita Kartini mulai terealisasikan, sekolahsekolah putri mulai didirikan dan emansipasi wanita selalu dibicarakan. Pada tahun 1912 didirikan sekolah Kartini di Semarang atas dorongan Van Deventer (Suhartono, 290). Kemudian di daerahdaerah semakin tumbuh pula sekolah-sekolah yang didirikan khusus untuk kaum wanita.

Selain Kartini, pelopor gerakan emansipasi perempuan Indonesia lainnya, antara lain: Raden Dewi Sartika (1884-1947), pada tahun 1915 menndirikan perkumpulan Pengasah Budi di Bandung; Rohanah Kudus, yang mendirikan perkumpulan Amai Setia (1914) di Kota Gadang, Bukittinggi, Sumatera Barat; Maria Walanda Maramis yang mendirikan Percintaan Ibu Kepada Anak Temurunnya (PIKAT) di Manado; dan masih banyak lagi srikandi-srikandi Indonesia yang menjadi pioneer dalam upaya memajukan derajat dan martabat kaum perempuan.

Pergerakan perempuan antara tahun 1920-1927, tidak melulu bergelut dalam sektor pendidikan saja, bahkan banyak organisasi-organisasi perempuan yang mulai terjun dalam pentas politik dan militer. Tujuan politik organisasi perempuan dilakukan bersama-sama organisasi sosial dan politik pada umumnya. Setiap organisasi pergerakan nasional yang berdiri umumnya diikuti oleh organisasi perempuan yang menjadi bagiannya. Seperti Aisyiyah didirikan pada tanggal 22 April 1917 di Yogyakarta, menjadi bagian dari Muhammadiyah, dan GERWANI (Gerakan Wanita Indonesia) yang menjadi bagian dari PKI (Partai Komunisme Indonesia). 
Bagaimanapun gerakan emansipasi dalam bingkai sejarah perempuan, merupakan kajian yang unik dan menarik untuk terus dikaji. Gerakan yang muncul oleh karena rasa ketidakadilan akan peranan dan kedudukan wanita yang selalu dianggap warga negara kelas dua. Setidaknya gerakan emansipasi ini pula harus disikapi dengan santun dan bijak. Jangan sampai gerakan ini kebablasan dari rambu-rambu yang sudah termaktub dalam agama. Bolehlah wanita meraih dari apa yang dicita-citakannya baik dalam bidang ekonomi, politik, hukum, sosial dan sebagainya, tapi janganlah melupakan kewajiban yang utama sebagai ibu rumah tangga yang mengayomi kehidupan dan pendidikan anak-anaknya. Dan jangan sampai pula gerakan pembebasan ini menjurus ke arah feminisme sekuler!

\section{Membuka Kotak Pandora}

Jauh sebelum pemikiran tentang emansipasi perempuan tersebut berkembang secara universal dan mempengaruhi perempuan untuk banyak berperan aktif dalam segala bidang kehidupan, sejarah telah menceritakan pasang surutnya peranan perempuan dalam upaya untuk mendobrak dan keluar dari jerat Kotak Pandora sebagai masyarakat "kelas dua." Adagium wanita merupakan masyarakat 'kelas dua' telah dikenal sejak zaman purba, tepatnya pada masa paleolitikum, yaitu ketika para kaum ibu hanya berada dalam rumah menunggu pasangan pria kembali dari berburu hewan. Berburu menjadi kegiatan laki-laki yang membedakannya dengan perempuan (Dina Dwikurniarini,2007:5). Masa Hindia Belanda, perempuan digambarkan pula sebagai second labour dalam kegiatan produksi. Pemerintah kolonial mengambil peran perempuan dalam masyarakat Hindia Belanda sebagai model dan beranggapan bahwa perempuan tidak bisa dan seharusnya tidak bisa atau tidak bekerja untuk mendapat upah.

Betapa pentingnya pendidikan bagi perempuan untuk keluar dari kotak Pandora tersebut. Apa yang dilakukan Kartini, Dewi Sartika, Rohana Kudus, dan pejuang-pejuang wanita lainnya menyadarkan kita bahwa keterasingan wanita dari pendidikan pada masa lampau telah membuat wanita ketika itu menjadi buta akan perubahan. Mereka terkungkung oleh adat istiadat kaku yang membatasi ruang gerak wanita untuk bangkit dari ketertindasan. Namun demikian, pendidikan saja tidak cukup, diperlukan sebuah kesadaran dari dalam jiwa sanubari seorang wanita untuk terus berjuang menuntut hak dan kodratnya sebagai wanita, juga diperlukan kesadaran dari dalam jiwa sanubari seorang laki-laki untuk memperlakukan wanita sebagai partner bukan sebagai 'babu' bahkan budak. Laki-laki dan perempuan harus saling bahu membahu bekerjasama demi kehidupan 
yang terberkati. Penulis menyadari pula betapa pentingnya kehadiran perempuan (seorang ibu) dalam sebuah rumah tangga, betapa berbedanya perilaku seorang suami yang sudah menikah bertahun dengan istrinya kemudian ditinggal wafat oleh sang tercinta. Seperti halnya sayur lodeh, perempuan merupakan santan, tanpanya sayur lodeh tersebut tentu asrep (tawar) rasanya.

Peranan wanita dari masa ke masa mengalami tranformasi yang tiada usainya, mencoba mencari suatu bentuk yang ideal di dalam tatanan kehidupan. Mencoba untuk keluar dari ketelingkungan makna tentang hakikat wanita yang dipersepsikan salah oleh kaum pria pada umumnya. Mencoba untuk berjuang menuntut haknya, demi satu kata, kesetaraan. Tapi adakalnya pula peranan wanita tersebut berada dalam persimpangan jalan, berada dalam onak dan duri yang merintangi jalannya, kemanakah harus melangkah dan mempukah untuk mengarungi itu semua, perempuan sendirilah yang harus menjawabnya! 


\section{Opini \\ Kabar Banten \\ RABU, 5 MEI 202 \\ Emansipasi dalam Bingkai Sejarah Perempuan}

Oleh:

Tubagus Umar Syarif Hadi Wibowo, M.Pd.

Dosen Jurusan Pendidika

"...Wanita dijajah pria sejak dulu, dijadikan perhiasan sangkar madu, tekuk lutut di sudut kerling wanita...."

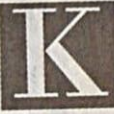
ATA-KATA di atas lirikakan penggala rik lagu yang cukup 50-an berjudul Sabda Alam. Lagu yang menggambarkan keadaan saling bertentangan antara dua makhluk utama ciptaan Tuhan didunia dan sekaligus ironiyang menggelayuti di zamannya. Menarik lagi makna lagu yang pernah dipopini, pria yang ditakdirkan berkuasa atas perempun nan lemah lembut lagimanperempuan nan lemah lembut sugut kerling wanita. Ini memberikan sinyal bagikaum pria, jangan sekali-sekali meregi kaum pria, jangan

Namun, dalam kenyataan zamannya, lagu tersebut dapat ditangkap permasalahan seputar wanita yang terus berusaha keluar dari stigma makhluk kelas dua. Sejarah pun nampaknya seaka mendiskriminasi hal tersebut, kaum pri sebagian besar mendominasi dalam ge rak langkah sejarah yang terjadi. Bahkan, ada anekdot, bahwa kata history itu berasal dari dua kata, his yang berarti kata yang menunjukkan kepunyaan (untuk pria) dan story yang berarti cerita. Jadi, dapat diartikan history ataus jarah sebagai ceritanya kaum pria, kar na sejarah dianggap hanya berisikan peranan yang dilakukan oleh kaum adam sebagai mesin sejarah tersebut. Tentunya juga tulisan ini tak berkenan menjustifikasi hal tersebut. Ada yang keliru dan harus diluruskan dalam pendapat tersebut. Nyatanya, sejarah kaum pria ataupun romantisme dan dinamika kaum pria dalam perjuangan merebut kemerdekaan. Di balik keheroikan romantisme, dan dinamika kaum pria dalam sejarah tersembunyi roh yan menjadi api panas membara.dalamme ngobarkan semangat sejarah itu. Ro itu adalah perempuan.

Kajian sejarah perempuan menjadi perhatian utama sejarawan untukmencari format barudalammengkaj berbagai permasalahan seputar perempua yang melingkupinya, truta emansipasi atau pembebasan perempuan yang sampai sekarang masih iperdebatkan da ten tinjau dari segi penggolongannya, Surtan sukkan gerakan mansi dalamsebagai gerak somis pok sosial yang dimobilisasi oleh tujuan dan ideologis, terutama pada fase getat sebagai organisasi formal.

Tuntuan persaman perempuan deTuntutan persamadierat padaabad ge-18bar ke-18bersaman do dustriyan and Gerakan emanip populer, yaitugerakan feminisme sepopuler, yaitu gerakan feminismah dipandang ada di Barat dan akhirnya menyebar ke berbagai belahan benua. Feminisme sebagai sebuah ide dan gerakan yang berusaha untuk memperramankeduduka derajat, hak dan kewajiban, ini tidak muncul tanpa sebab.

Di dunia Barat (Eropa dan AS) maupun dalam pandangan agama tertent kedudukan wanita sebelum ide in muncul, sungguh memprihatinkan. Sebagai ide yang revolusioner, feminism berusaha membebaskan perempuan da laki-laki dari ketertindasan. Perempuan dianggap tertindas, karena pemikirannya yang tidak tercerahkan, (Ita Mutiar Dewi, 2007:115). Pada intinya feminism melihat duniayang ada sejak dulu hingga kini bersikap tidak adil terhada wanita akibat adanya perbedaan gender (gender differences) yang melahirkan ketidakadilan gender (gender in equalities). Ketidakadilan gender termanifestasi dalam berbagaibentuk ketidakadilan, yakni: (1) marginalisasi atau proses pemiskinan ekonomi,(2) subordinasi atau anggapan tidak

Para pelopor emansipasi Gerakan emansipasi perempuan dindonesia baru menampakkan taringnya ketika era pergerakan nasional akhir abad ke-19. Sebelumnya, keadaan wanita pada waktu itu (masa kolonial) masih ada dalam konservatisme dan sangat terikat oleh adat. Pengajaran di sekolahekolah hanya diperuntukkan bagi anak laki-laki, sedangkan anak-anak perempuan hanya mendapat pendidikan rumph ataulingkungan keluarga dan pencidikan yang diperolehnya dia seorang bu rumah tangga yang baik, (Suhartono, 1994). Sampai-sampaiada adagium yan Siti Nurbayaitu hanya berkutat pada persoalan di dapur, sumur, bahkan yang soalan di dapur, sumur,

Adalah Raden Ajeng Kartini, seorang vanita bangsawan yang hidup di tengah作 satu pelopor gerakan emansipasiwan I lusion vatism dan rigidnya ikatan adat yan mengungkung fleksibilitas wanita unkun keinginanny Kartini merupakan salah satu da sedikit perempuan Indonesia yang menguasai bahasa Belanda dengan baik. $\mathrm{K}$ mampuannya dalam berbahasa Beland merupakan modal pengetahuan yan amat berharga untuk berhubungan de ngan teman-temannya terutama da Eropa. Korespondensi Kartini denga wanita modern dari Eropa sepertiSteela sekuler! Zeehandelaar, semakin membuka wanita. Hal inilah yang mendoron Kartini untuk memajukan kaum wanita Indonesiayang saat itu berada dalam status sosial yang rendah, (Sudrajat. 2007:31)

Kartini sangat giat sekali memajuka anita Indonesia saat itu melaluibidan pendidikan. Hanya melalui pendidika dan pelajaran yang baik, maka keduduka dan kebahagiaan wanita dapat diperbaki dan setaraf dengan kaum pria dala kehidupan di masyarakat. Hal ini tanpak dalam buku Habis Gelap Terbitlah Terang, oleh Kartini terjemahan Armin Pane, (Sudiyo, 2002:11). Dalam waktu mulaitérealisasikan, sekolah-sekolah putri mulai didirikan dan emansipasi wanita selalu dibicarakan. Pada 1912 didirikan sekolah Kartini di Semarang atas dorongan Van Deventer, (Suhartono, 290). Kemudian, di daerah-dacrah semakin tumbuh juga sekolah-sekolah ya didirikankhusus untuk kaum wanita. Selain Kartini, pelopor gerakan emansipasiperent antara lain: Raden Devisutike (188, 1947), pada 1915 diding Ku Kudus, yang muk Anaris tinggi, Sumatera Barat, Man Walan Maramis yang di Mañado; dan masih banyak lagi di Manado; dan masih banyak lagi srikandi-srikandi Indonesia yang menjadi pionir dala

rajat dan martabat kaum pena Pergerakan perempuan antar 1927, tidak pel tor pen ganisasi-organisasi perempuan yan riliter Tuj molitikereniserem militer. Tujuan politik organisasi perempua dicitik pada umumny setisosiasi perakan nasion Setiap organisasi pergerakan nasieh organisasi perempuan yang menjad berti Aisyiyah didirika a 2 A ril is di Xog akarta, menjadi bagian dari Muhammadiyah da GERWANI (Gerakan Wanita Indone ia) yang menjadibagian dari PKI ( $\mathrm{Pa}$ tai Komunisme Indonesia)

Bagaimanajuga gerakan emansipasi dalam bingkai sejarah perempuan, merupakan kajian yang unik dan menarik untuk terus dikaji. Gerakan yang muncul oleh karena rasa ketidakadilan akan peranan dan kedudukan wanita yang selalu dianggap warga negara kelas dua. Setidaknya gerakan emansipasi ini juga harus disikapi dengan santun dan bijak. Jangan sampai gerakan ini kebablasan dari zambu-rambu yang sudah termaktub dalam agama. Bolehlah wanita meraih dari apa yang dicita-citakannya baik dalam bidang ekonomi, politik, hukum, sosial, dan sebagainya, tetapi janganlah melupakan kewajiban yang utama sebaga bu rumah tangga yang mengayomi kehidupan dan pendidikan anak-anaknya dan jangan sampai juga gerakan pemebasan ini menjurus ke arah feminisme

Membuka kotak Pandora Jauh sebelum pemikiran tentang emansipasi perempuan tersebut berkembang secara univeral dan memengaruhi perempuan untak berperan altip dalo hidupan, sejarah telah menceritakan pasang surutnya peranan perempuan eluar dari jerat kotak Pandora sebaga 'masyar ' (a) elah dikenal sejak zaman purba, tepatnya pada cria kemri riburumenja kegiatan laki-laki yang membejadi kempuan, (Dina Dwikurniarini, 2007:5). Masa Hindia Belanda perempuan digambarkan jugelanda, peremplabour dalam kegiatan produksi. Pemerintah kolonial mengambil peran perempuan dalam masyarakat Hindia Belanda sebagai model dan beranggapan, bahwa perempuan tidak bis dan seharusnya tidak bisa atau tida bekerja untuk mendapat upah.

Betapa pentingnya pendidikan bag perempuan untuk keluar dari kotak Pandoratersebut. Apayang dilakukan Kartini, Dewi Sartika, Rohana Kudus, dan pejuang-pejuang wanita lainnya menyadarpendidikan pada masa lampau telah membuat wanitaketikaitumenjadi buta akan perubahan. Mereka terkungkung oleh adat istiadat kaku yang membatasi ruang gerak wanita untuk bangkit dari ketertindasan. Namun demikian, pendidikan saja tidak cukup, diperlukan sebuah kesadaran daridalam jiwa sanubari seorang wanita untuk terus berjuangmenuntut hak dan kodratnya sebagai wanita, juga diperlukan kesadaran dari dalam jiwa sanubati seorang laki-laki untuk memperlakukan wanita sebagai partner bukan sebagai 'babu', bahkan budak. Laki-laki dan perempuan harus saling bahumembahu bekerja sama demi kehidupan yang terberkati. Penulis menyadarijuga seorang ibu) dalam sebuah rumah tanga, betapa berbedanya perilaku seorang suamiyang sudah menkah bertahun dengan istrinya, kemudian ditinggal wafa oleh sang tercinta. Seperti halnya sayur lodeh, perempuan merupakan santan, tanpanya sayur lodeh tersebut tentu asep (tawar) rasanya.

Peranan wanita dari masa ke masa mengalami tranformasi yang tiada usainya, mencoba mencari suatubentuk yang ideal di dalam tatanan kehidupan. Mencoba untuk keluar dar ketelingkungan maknatent wanita yang dipersepsikan sa kaum pria pada umumnya. Mencoba untuk berjung mon mi satu kata, keran wanita terse- 